\title{
DNA barcoding supports identification of Malacobdella species (Nemertea: Hoplonemertea)
}

\author{
Jose E F Alfaya ${ }^{1,2}$, Gregorio Bigatti ${ }^{1,2}$, Hiroshi Kajihara ${ }^{3}$, Malin Strand ${ }^{4}$, Per Sundberg ${ }^{5}$ and Annie Machordom ${ }^{6 *}$
}

\begin{abstract}
Background: Nemerteans of the genus Malacobdella live inside of the mantle cavity of marine bivalves. The genus currently contains only six species, five of which are host-specific and usually found in a single host species, while the sixth species, M. grossa, has a wide host range and has been found in 27 different bivalve species to date. The main challenge of Malacobdella species identification resides in the similarity of the external morphology between species (terminal sucker, gut undulations number, anus position and gonad colouration), and thus, the illustrations provided in the original descriptions do not allow reliable identification. In this article, we analyse the relationships among three species of Malacobdella: M. arrokeana, M. japonica and M. grossa, adding new data for the M. grossa and reporting the first for M. japonica, analysing 658 base pairs of the mitochondrial cytochrome $c$ oxidase subunit I gene $(\mathrm{CO})$. Based on these analyses, we present and discuss the potential of DNA barcoding for Malacobdella species identification.

Results: Sixty-four DNA barcoding fragments of the mitochondrial COI gene from three different Malacobdella species (M. arrokeana, M. japonica and M. grossa) are analysed (24 of them newly sequenced for this study, along with four outgroup specimens) and used to delineate species. Divergences, measured as uncorrected differences, between the three species were M. arrokeana-M. grossa 11.73\%, M. arrokeana-M. japonica 10.62\% and M. grossa-M. japonica 10.97\%. The mean intraspecific divergence within the ingroup species showed a patent gap with respect to the interspecific ones: $0.18 \%$ for M. arrokeana, $0.13 \%$ for M. grossa and $0.02 \%$ for M. japonica (ranges from 0 to $0.91 \%$ ).
\end{abstract}

Conclusions: We conclude that there is a clear correspondence between the molecular data and distinguishing morphological characters. Our results thus indicate that some morphological characters are useful for species identification and support the potential of DNA barcoding for species identification in a taxonomic group with subtle morphological external differences.

Keywords: DNA barcoding; COl gene; Bivalvia; Entocommensal nemertean; Malacobdella

\section{Background}

The phylum Nemertea is a group of organisms whose identification and taxonomy requires specialized methods, mainly histology. Recently, molecular methods have been a useful tool for ascertaining the actual biodiversity of these worms and increasing our knowledge of several of the problematic species (Chen et al. 2010; Fernández-Álvarez and Machordom 2013; Kvist et al. 2013). The nemertean genus Malacobdella de Blainville 1827 originally contained 13 nominal species, of which six are currently regarded as valid (Gibson 1995; Ivanov et al. 2002). The species of the

\footnotetext{
* Correspondence: annie@mncn.csic.es

${ }^{6}$ Museo Nacional de Ciencias Naturales (MNCN), CSIC, José Gutiérrez Abascal, 2, 28006 Madrid, Spain

Full list of author information is available at the end of the article
}

genus are entocommensal in the mantle cavity of marine bivalves, mainly from the subclass Heterodonta (Jensen and Sadeghian 2005). The phylogenetic position of the genus Malacobdella is controversial within the phylum, mainly because this genus is always represented by sequences belonging only to the species $M$. grossa (Thollesson and Norenburg 2003; Andrade et al. 2012), the most studied and cosmopolitan species. The Malacobdella species are distributed in distant locations around the world: M. japonica, M. macomae and M. siliquae were described in the eastern (Japan) and western (west coast of the USA) Pacific Ocean; M. grossa was described in the Pacific (west coast of the USA) and Atlantic Ocean (northern Europe); and M. arrokeana was the only southern species described in the South Atlantic Ocean (Ivanov et al. 2002 
and references herein). The geographic distribution of the genus requires a huge sampling effort to work with all species. Identifying Malacobdella species is difficult because important diagnostic features were not initially recognized and thus not mentioned in earlier descriptions (Ivanov et al. 2002). In addition, the similarity of the external morphology between species (terminal sucker, number of intestinal loops (undulations), anus position and immature gonad colouration) and the illustrations provided in the original descriptions of the species do not allow reliable identification. There is little knowledge about the biology of Malacobdella species. The genus Malacobdella belongs to the hoplonemertean non-pilidiophora species (Thollesson and Norenburg 2003); this group presents direct development and non-feeding planuliform larvae (Maslakova and von Döhren 2009). However, there are no studies on its larval development, dispersion and settlement.

The host specificity of the Malacobdella species is generally high; five of the six known species have been reported from only one or two bivalve species: $M$. arrokeana Ivanov et al. 2002 from Panopea abbreviata (Heterodonta: Hiatelloidea) (Ivanov et al. 2002; Alfaya et al. 2013); M. japonica Takakura 1897 from Spisula sachalinensis (Heterodonta: Mactroidea) (Takakura 1897); M. macomae Kozloff 1991 from Macoma nasuta and Macoma secta (Heterodonta: Tellinoidea) (Kozloff 1991); M. minuta (Coe 1945) from Yoldia cooperii (Protobranchia: Nuculanoidea) (Coe 1945); and M. siliquae Kozloff 1991 from Siliqua patula (Heterodonta: Solenoidea) (Kozloff 1991). The sixth species, M. grossa, is the type specimen of the genus and was originally obtained from Dosinia exoleta (Linnaeus 1758) (Heterodonta: Veneroidea) (Müller 1776). However, the most complete morphological description of $M$. grossa, reported by Riepen (1933), was based on material from Arctica islandica (Linnaeus 1767) (Heterodonta: Arcticoidea). Nemerteans are traditionally identified and classified using morphological criteria, but the relatively low number of qualitative morphological characters, the lack of adequate fixation procedures for histological studies, vague descriptions in the original papers and the paucity of species-specific characters make species delimitation problematic, especially when comparing closely related species (Chen et al. 2010; Sundberg et al. 2010; Fernández-Álvarez and Machordom 2013; Kvist et al. 2013). The difficulty of morphological recognition of a great part of the more than 1,280 species included in the phylum Nemertea has been previously discussed (Andrade et al. 2012; Sundberg and Strand 2010; Kvist et al. 2013, among others), and different authors have advocated new tools and comprehensive studies for correctly identifying species and thus providing accurate biodiversity knowledge. The combination of molecular and morphological methods has been useful in elucidating nemertean taxonomy in other genera (Sundberg et al. 2009; Junoy et al. 2010; Puerta et al. 2010; Kajihara et al. 2011; Taboada et al. 2013). DNA barcoding accelerated the discovery ratio of new species (Wiens 2007) and identified some inconsistencies between species assignment and previously sequenced specimens (Kvist et al. 2013). Nevertheless, only a small number of nemerteans have been analysed through DNA barcoding (Sundberg et al. 2009; Chen et al. 2010; Fernández-Álvarez and Machordom, 2013; Kvist et al. 2013; Strand et al. 2014). The potential use of DNA barcoding needs to be substantiated in well-established taxonomic groups before it can be fully exploited in all nemertean genera. Currently, only $6 \%$ of the phylum Nemertea has an associated barcode sequence (Bucklin et al. 2011; Fernández-Álvarez and Machordom 2013).

Our objectives are to provide the most comprehensive molecular data set for the Malacobdella genus and test the usefulness of this data in the delimitation of the three most widely distributed species of the Malacobdella genus, and to provide for the first time $\mathrm{COI}$ sequences for $M$. japonica. We also estimate the phylogenetic relationship between 64 individuals from the 3 species based on partial sequences of $C O I$.

\section{Methods}

\section{Specimen collection and sequences used}

Thirty-eight sequences of $M$. arrokeana were obtained from specimens collected at three northern Patagonian gulfs in Argentina (previously studied by Alfaya et al. 2013): San Matías Gulf $(n=23)$, San José Gulf $(n=7)$ and Nuevo Gulf $(n=8)$ (Table 1). Each of the M. arrokeana specimens was collected from a different host specimen of $P$. abbreviata. Specimens of $M$. japonica were collected from 15 different $S$. sachalinensis bivalves at Shinryu Beach in Akkeshi, Hokkaido, Japan. Individuals of $M$. grossa $(n=11)$ were obtained from different $A$. islandica clams in the waters of Tjärnö, Skagerak, Sweden. Additionally, two M. grossa COI sequences from GenBank (HQ848591 and AJ436905, from Tjärnö, Sweden, and the White Sea, Russia, respectively) were included in the analysis (Table 1). Fresh specimens were stored in absolute ethanol, and DNA was extracted from preserved tissues using a DNeasy extraction kit (Qiagen, Inc., Hilden, Germany), following the manufacturer's protocol.

To test for the monophyly of the genus, we sequenced Ramphogordius sanguineus specimens collected along the Argentinean coast to use as the outgroup. We also used $\mathrm{COI}$ sequences available from GenBank for nemerteans that are closely related to Malacobdella and have been previously used in other phylogenetic studies (Andrade et al. 2012; Mateos and Giribet 2008; Thollesson and Norenburg 2003), including two $R$. sanguineus outgroup sequences (Table 1). 
Table 1 List of species used in the analysis, including the sample locality, number of specimens analysed ( $N$ ) and GenBank accession numbers

\begin{tabular}{|c|c|c|c|c|c|c|}
\hline Species & Specimen ID & Locations & Position & $N$ & GenBank acc. number & $\begin{array}{l}\text { References or voucher } \\
\text { numbers }^{\mathrm{a}}\end{array}$ \\
\hline \multirow[t]{38}{*}{ Malacobdella arrokeana } & Ma1 & San Matías Gulf, Argentina & $40^{\circ} 50^{\prime} \mathrm{S} / 65^{\circ} 04^{\prime} \mathrm{W}$ & 23 & $J X 220596$ & CNP-INV 1879 \\
\hline & Ma2 & & & & JX220597 & CNP-INV 1880 \\
\hline & Ma4 & & & & $J X 220599$ & CNP-INV 1881 \\
\hline & Ma5 & & & & $J X 220600$ & CNP-INV 1882 \\
\hline & Ma6 & & & & $J X 220601$ & CNP-INV 1883 \\
\hline & $\mathrm{Ma} 7$ & & & & $J X 220602$ & CNP-INV 1884 \\
\hline & Ma8 & & & & $J X 220603$ & CNP-INV 1885 \\
\hline & Ma9 & & & & $J \times 220604$ & CNP-INV 1886 \\
\hline & Ma10 & & & & $J X 220605$ & CNP-INV 1887 \\
\hline & Ma11 & & & & JX220606 & CNP-INV 1888 \\
\hline & Ma13 & & & & $J X 220607$ & CNP-INV 1889 \\
\hline & Ma14 & & & & JX220608 & CNP-INV 1890 \\
\hline & Ma15 & & & & $J X 220609$ & CNP-INV 1891 \\
\hline & Ma16 & & & & $J X 220610$ & CNP-INV 1892 \\
\hline & Ma17 & & & & $J \times 220611$ & CNP-INV 1893 \\
\hline & Ma18 & & & & $J X 220612$ & CNP-INV 1894 \\
\hline & Ma19 & & & & $J X 220613$ & CNP-INV 1895 \\
\hline & Ma20 & & & & $J X 220614$ & CNP-INV 1896 \\
\hline & Ma21 & & & & $J X 220615$ & CNP-INV 1897 \\
\hline & Ma22 & & & & $J \times 220616$ & CNP-INV 1898 \\
\hline & Ma23 & & & & $J X 220617$ & CNP-INV 1899 \\
\hline & Ma24 & & & & $J X 220618$ & CNP-INV 1900 \\
\hline & Ma27 & & & & $J \times 220620$ & CNP-INV 1901 \\
\hline & MaA1 & Nuevo Gulf, Argentina & $42^{\circ} 55^{\prime} \mathrm{S} / 64^{\circ} 30^{\prime} \mathrm{W}$ & 7 & $J X 220621$ & CNP-INV 1902 \\
\hline & MaA2 & & & & JX220622 & CNP-INV 1903 \\
\hline & MaA3 & & & & $J \times 220623$ & CNP-INV 1904 \\
\hline & MaA4 & & & & $J X 220624$ & CNP-INV 1905 \\
\hline & MaA6 & & & & $J X 220625$ & CNP-INV 1906 \\
\hline & MaB1 & & & & $J X 220626$ & CNP-INV 1907 \\
\hline & MaB2 & & & & $J X 220627$ & CNP-INV 1908 \\
\hline & GSJ5A & San José Gulf, Argentina & $42^{\circ} 20^{\prime} \mathrm{S} / 64^{\circ} 10^{\prime} \mathrm{W}$ & 8 & $J X 220629$ & CNP-INV 1909 \\
\hline & GSJ5B & & & & $J \times 220630$ & CNP-INV 1910 \\
\hline & GSJJ5 & & & & $J X 220638$ & CNP-INV 1911 \\
\hline & GSJJ6 & & & & $J X 220639$ & CNP-INV 1912 \\
\hline & GSJJ7 & & & & $J \times 220640$ & CNP-INV 1913 \\
\hline & GSJJ8 & & & & JX220641 & CNP-INV 1914 \\
\hline & GSJJ9 & & & & $J X 220642$ & CNP-INV 1915 \\
\hline & GSJJ10 & & & & $J X 220643$ & CNP-INV 1916 \\
\hline \multirow[t]{5}{*}{ M. japonica } & Mja1 & Hokkaido, Japan & $43^{\circ} 3^{\prime} \mathrm{N} / 144^{\circ} 51^{\prime} \mathrm{E}$ & 13 & KF597252 & MNCN-5.02/3 \\
\hline & Mja2 & & & & KF597253 & MNCN-5.02/4 \\
\hline & Mja4 & & & & KF597254 & MNCN-5.02/5 \\
\hline & Mja5 & & & & KF597255 & MNCN-5.02/6 \\
\hline & Mja6 & & & & KF597256 & MNCN-5.02/7 \\
\hline
\end{tabular}


Table 1 List of species used in the analysis, including the sample locality, number of specimens analysed $(N)$ and GenBank accession numbers (Continued)

\begin{tabular}{|c|c|c|c|c|c|c|}
\hline & Mja7 & & & & KF597257 & MNCN-5.02/8 \\
\hline & Mja8 & & & & KF597258 & MNCN-5.02/9 \\
\hline & Mja10 & & & & KF597259 & MNCN-5.02/10 \\
\hline & Mja11 & & & & KF597260 & MNCN-5.02/11 \\
\hline & Mja12 & & & & KF597261 & MNCN-5.02/12 \\
\hline & Mja13 & & & & KF597262 & MNCN-5.02/13 \\
\hline & Mja14 & & & & KF597263 & MNCN-5.02/14 \\
\hline & Mja15 & & & & KF597264 & MNCN-5.02/15 \\
\hline \multirow[t]{13}{*}{ M. grossa } & Mgrossa197 & Tjärnö, Sweden & $58^{\circ} 53^{\prime} \mathrm{N} / 011^{\circ} 5^{\prime} \mathrm{E}$ & 12 & KF597241 & MNCN-5.02/16 \\
\hline & Mgrossa198 & & & & KF597242 & MNCN-5.02/17 \\
\hline & Mgrossa201 & & & & KF597243 & MNCN-5.02/18 \\
\hline & Mgrossa202 & & & & KF597244 & MNCN-5.02/19 \\
\hline & Mgrossa203 & & & & KF597245 & MNCN-5.02/20 \\
\hline & Mgrossa204 & & & & KF597246 & MNCN-5.02/21 \\
\hline & Mgrossa205 & & & & KF597247 & MNCN-5.02/22 \\
\hline & Mgrossa206 & & & & KF597248 & MNCN-5.02/23 \\
\hline & Mgrossa207 & & & & KF597249 & MNCN-5.02/24 \\
\hline & Mgrossa208 & & & & KF597250 & MNCN-5.02/25 \\
\hline & Mgrossa209 & & & & KF597251 & MNCN-5.02/26 \\
\hline & Mgrossa GB 1 & & & & HQ848591 & Andrade et al. (2012) \\
\hline & Mgrossa GB 2 & White Sea, Russia & & 1 & AJ436905 & $\begin{array}{l}\text { Thollesson and } \\
\text { Norenburg (2003) }\end{array}$ \\
\hline \multirow[t]{6}{*}{ Ramphogordius sanguineus } & R.s1 & Maine, USA & & 1 & HQ848580 & Andrade et al. (2012) \\
\hline & R.s2 & Anglesey, UK & & 1 & AJ436938 & $\begin{array}{l}\text { Thollesson and } \\
\text { Norenburg (2003) }\end{array}$ \\
\hline & Li2 & Nuevo Gulf, Argentina & & 4 & KM387723 & CNP-INV 1917 \\
\hline & Li3 & & & & KM387724 & CNP-INV 1918 \\
\hline & Li4 & & & & KM387725 & CNP-INV 1919 \\
\hline & Li5 & & & & KM387726 & CNP-INV 1920 \\
\hline Amphiporus lactifloreus & A.l & Anglesey, UK & $53^{\circ} 17^{\prime} \mathrm{N} / 04^{\circ} 03^{\prime} \mathrm{W}$ & 1 & HQ848611 & Andrade et al. (2012) \\
\hline Paradrepanophorus crassus & P.C & Galicia, Spain & & 1 & HQ848603 & \\
\hline \multirow[t]{2}{*}{ Geonemertes pelaensis } & G.p1 & St. Davis, Bermuda & & 2 & HQ848592 & \\
\hline & G.p2 & Bermuda & & & EU255602 & Mateos and Giribet (2008) \\
\hline
\end{tabular}

${ }^{a}$ Voucher numbers are given only for Malacobdella arrokeana specimens from the previous work of Alfaya et al. (2013), and for M. grossa and M. japonica newly sequenced here. MNCN, Museo Nacional de Ciencias Naturales (Madrid, Spain); CNP-INV, Invertebrate Collection of the Centro Nacional Patagónico (Argentina).

\section{PCR amplification and sequencing}

Partial COI sequences were amplified by PCR using the following primers: LCO1490 (5'-GGTCAACAAATCA TAAAGATATTGG-3') (Folmer et al. 1994) and COI-H (5' -TCAGGGTGACCAAAAAATCA-3') (Machordom et al. 2003). Amplification was carried out in a 50- $\mu$ l final volume reaction consisting of $5 \mu \mathrm{l}$ buffer containing $10 \times 2 \mathrm{mM} \mathrm{MgCl} 2,1 \mu \mathrm{l}$ dNTP mix (10 mM), $0.4 \mu \mathrm{l}$ of Taq DNA polymerase $(5 \mathrm{U} / \mu \mathrm{l}$ ) (Biotools, Madrid, Spain), 1-3 $\mu$ l of genomic DNA and $0.8 \mu$ l of each primer $(10 \mu \mathrm{M})$. Thermal cycling conditions were an initial 4-min denaturation at $94^{\circ} \mathrm{C}$, followed by 40 cycles of $45 \mathrm{~s}$ at $94^{\circ} \mathrm{C}, 1 \mathrm{~min}$ at $45^{\circ} \mathrm{C}$ and $1 \mathrm{~min}$ at $72^{\circ} \mathrm{C}$, ending with a final $10-\mathrm{min}$ extension at $72^{\circ} \mathrm{C}$. The products were visualized under blue light in $0.8 \%$ agarose gels stained with SYBR Safe (Invitrogen, Carlsbad, CA, USA), with co-migrating 100-bp or 1-kb ladder molecular weight markers. The amplification products (around $700 \mathrm{bp}$ ) were purified by ethanol precipitation. Both strands were sequenced using the BigDye Terminator sequencing kit and an ABI PRISM 3730 DNA Sequencer (Applied Biosystems, Grand Island, NY, USA). 


\section{Data analysis}

Special alignment was unnecessary as the COI sequences from the analysed species did not present any gaps. Phylogenetic analyses were performed with PAUP 4.0 b10 (Swofford 2000) for maximum parsimony (MP) and maximum likelihood (ML), and with MrBayes 3.2 (Huelsenbeck 2000; Huelsenbeck and Ronquist 2001) for Bayesian inference (BI). MP parameters included a heuristic search with tree bisection-reconnection (TBR) branch swapping and ten random additions. ML was also estimated through a heuristic search, with stepwise addition, applying the TIM $3+\mathrm{G}+\mathrm{I}$ (transitional) model (Posada 2003). Two runs of $5,000,000$ generations were performed for BI, sampling one tree per 1,000 replicates. The model that best fits the data (TIM3 $+\mathrm{I}+\mathrm{G}$ ) was found with jModelTest (Posada 2008). Branch supports for MP (1,000 replicates) and ML (150 replicates) were determined by bootstrapping (Felsenstein 1985) and by posterior probabilities (after a burn-in of $20 \%$ of the obtained trees) for BI.

\section{Results}

According to original descriptions, the three studied species of the Malacobdella genus are very similar in their external morphology but differ in internal morphological characters. Malacobdella arrokeana differs from $M$. japonica and $M$. grossa in the origin of the proboscis retractor muscle. This muscle is curved dorsally and attaches to the internal body wall in $M$. arrokeana, whereas in $M$. grossa, it originates ventrally next to the terminal sucker (Table 2). In $M$. japonica, the muscle also originates ventrally but ends freely in the parenchyma (Table 2). M. japonica differs from $M$. arrokeana and $M$. grossa in the position of the nerve commissure. In $M$. japonica, the posterior nerve commissure is situated around the terminal sucker, while in the other two species, the nerve commissure is situated dorsally in the posterior part of the intestine just before the anus (Table 2).

M. grossa also differs from $M$. arrokeana and $M$. japonica in the position of the excretory pores, being ventro-lateral in $M$. grossa and dorso-lateral in $M$. arrokeana and $M$. japonica. The rhynchocoel occupies most of the body length in the three species, up to $80 \%$ to $90 \%$ with the proboscis occupying two thirds of the rhynchocoel. Gonad colouration varies according to species and stage of gonad development. Generally, the gonads are dark olive green in colour in mature specimens of M. grossa, rosy or purple in mature $M$. arrokeana and rosy in mature $M$. japonica (Figure 1, Table 2). However, gonad colouration is always white in immature specimens (Figure 1A).

The COI fragments sequenced for $M$. arrokeana, $M$. grossa and M. japonica were 658 bp in length. These sequences were deposited in GenBank under accession numbers KF597241 to KF597264. The different phylogenetic analyses resulted in the same topology, with high support within the ingroup (Figure 2). The divergences, measured as uncorrected distances (percentage of nucleotide substitutions), between the three species were as follows: M. arrokeana-M. grossa $11.73 \%$, M. arrokeanaM. japonica $10.62 \%$ and M. grossa-M. japonica $10.97 \%$. There was a clear gap between these interspecific divergences and the intraspecific ones: the mean intraspecific divergence within the ingroup species was $0.18 \%$ for M. arrokeana (range $0 \%$ to $0.92 \%$ ), $0.13 \%$ for $M$. grossa (range $0 \%$ to $0.61 \%$ ) and $0.02 \%$ for $M$. japonica (range $0 \%$ to $0.15 \%)$. It is noteworthy that within the R. sanguineus sequences selected as the outgroup (Table 1), the divergence between one (GenBank accession number

Table 2 Characteristic features of the analysed Malacobdella species

\begin{tabular}{|c|c|c|c|}
\hline Features & M. arrokeana (Ivanov et al. 2002) & M. japonica (Takakura 1897) & M. grossa (Müller 1776) \\
\hline Excretory pores & Dorso-lateral (40\% of length) & $\begin{array}{l}\text { Dorso-lateral (25\% of length) } \\
\text { (Yamaoka 1940) }\end{array}$ & Ventro-lateral \\
\hline Proboscis length & Most of the rhynchocoel, 80 to 90 & $\begin{array}{l}\text { Two thirds of the rhynchocoel length } \\
\text { (Yamaoka 1940) }\end{array}$ & Two thirds of the rhynchocoel length \\
\hline Proboscis retractor muscle & $\begin{array}{l}\text { Curved dorsally and attached to the } \\
\text { body muscular wall }\end{array}$ & $\begin{array}{l}\text { Originates ventrally and ends freely in } \\
\text { the parenchyma (Yamaoka 1940) }\end{array}$ & $\begin{array}{l}\text { Originates ventrally next to the terminal } \\
\text { sucker (Riepen 1933) }\end{array}$ \\
\hline Ovary colour (mature) & White or purple (Teso et al. 2006) & Rosy (Yamaoka 1940) & $\begin{array}{l}\text { Olive green or yellowish green } \\
\text { (Gibson 1968) }\end{array}$ \\
\hline Testicle colour (mature) & Pale rose (Teso et al. 2006) & White (Yamaoka 1940) & Rosy or pinkish hue (Gibson 1968) \\
\hline Nerve commissure & $\begin{array}{l}\text { Dorsal in the posterior part of the } \\
\text { intestine just before the anus }\end{array}$ & $\begin{array}{l}\text { Far behind the anus along the posterior } \\
\text { margin of the sucker (Yamaoka 1940) } \\
\text { (posterior around the terminal sucker) }\end{array}$ & $\begin{array}{l}\text { Dorsal in the posterior part of intestine, } \\
\text { above the anus }\end{array}$ \\
\hline Host specificity & High (only in Panopea abbreviata) & High (only in Spisula sachalinensis) & Low (27 species) \\
\hline Geographic distribution & $\begin{array}{l}\text { South Atlantic Ocean (from Uruguay } \\
\text { to north Patagonian gulfs) }\end{array}$ & North Pacific Ocean (northern Japan) & $\begin{array}{l}\text { North Atlantic Ocean (Europe and } \\
\text { North America) North Pacific Ocean } \\
\text { (North America) }\end{array}$ \\
\hline
\end{tabular}




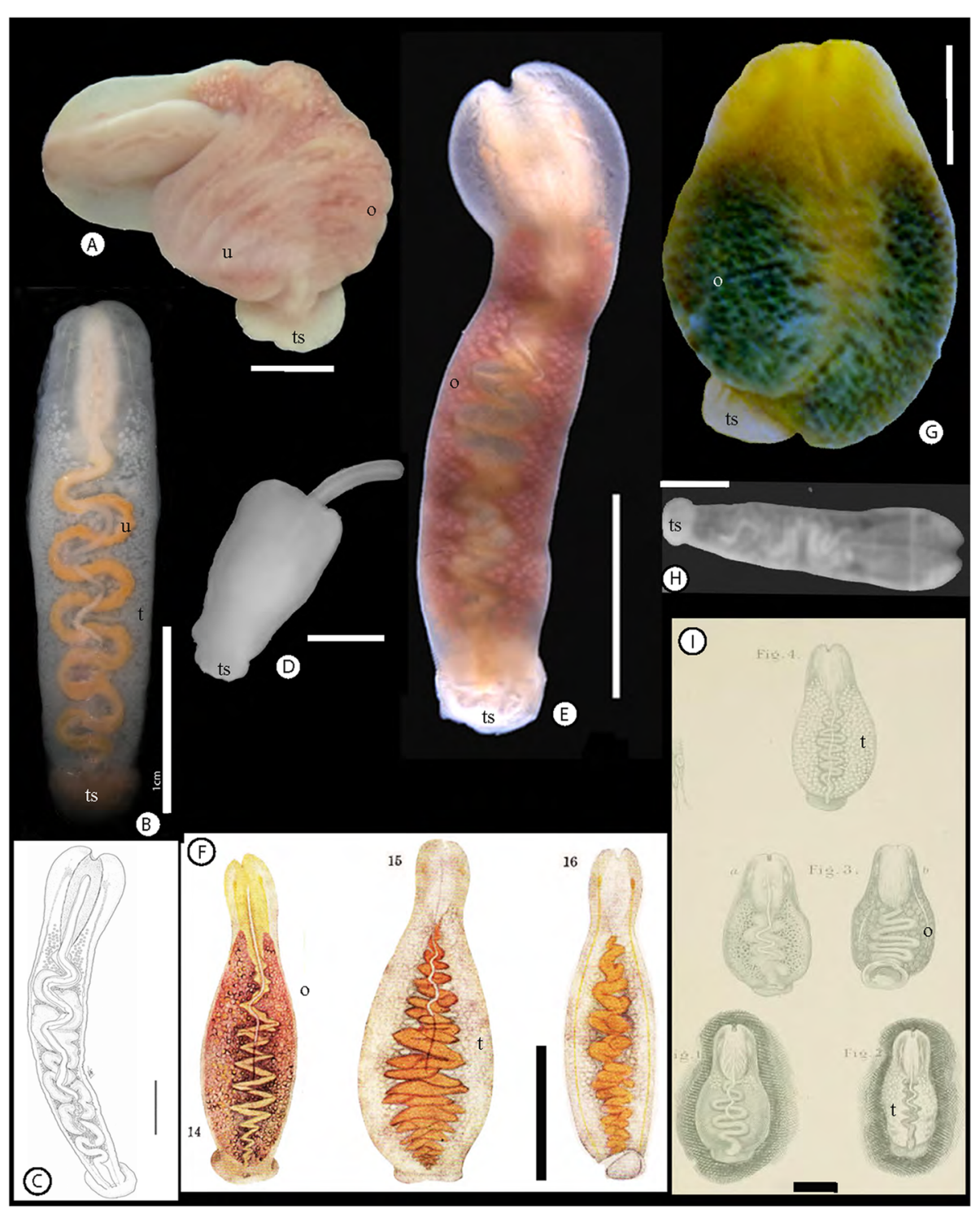

Figure 1 Specimens of the different Malacobdella species here analysed. Malacobdella arrokeana: (A) unrelaxed mature female, (B) relaxed male, (C) original illustration (Ivanov et al. 2002) and (D) immature specimen (scale bars: A, B: 10 mm; C: 3.5 mm, D: 1 mm). Malacobdella japonica: (E) relaxed mature female and (F) original illustration (Yamaoka 1940) (scale bars: E: 10 mm; F: 1 mm). Malacobdella grossa: (G) unrelaxed mature female, (H) immature specimen and (I) original illustration (Riepen 1933) (scale bars: A: 10 mm, B: 4 mm; C: 1 mm). Abbreviations: ts, terminal sucker; $\mathrm{u}$, gut undulations; $\mathrm{O}$, ovaries; t, testes.

HQ848580) of the sequences and the rest of the sequences of this species (GenBank AJ436938 and those collected by the authors) was more than $15 \%$ (15.75\%), while the maximum divergence between the others was 100 -fold lower (around 0.15\%), suggesting that the COI sequence HQ848580 from GenBank is not actually from $R$. sanguineus. The five substitutions found among the $M$. grossa haplotypes were synonymous, as was the unique change among specimens of $M$. japonica, while of the 15 substitutions found among the haplotypes of M. arrokeana, three lead to amino acid changes.

\section{Discussion}

As previously mentioned, nemerteans of the Malacobdella genus are very difficult to identify based only on external characters. Rather, it is the internal morphology that provides the main taxonomic features used for identification, which can be differentiated only after a rigorous histological procedure. The genetic analysis performed here clearly shows that the distinguishing internal morphological differences used to separate the three species of Malacobdella analysed are concordant with differences in a fragment of the COI gene. However, previous 


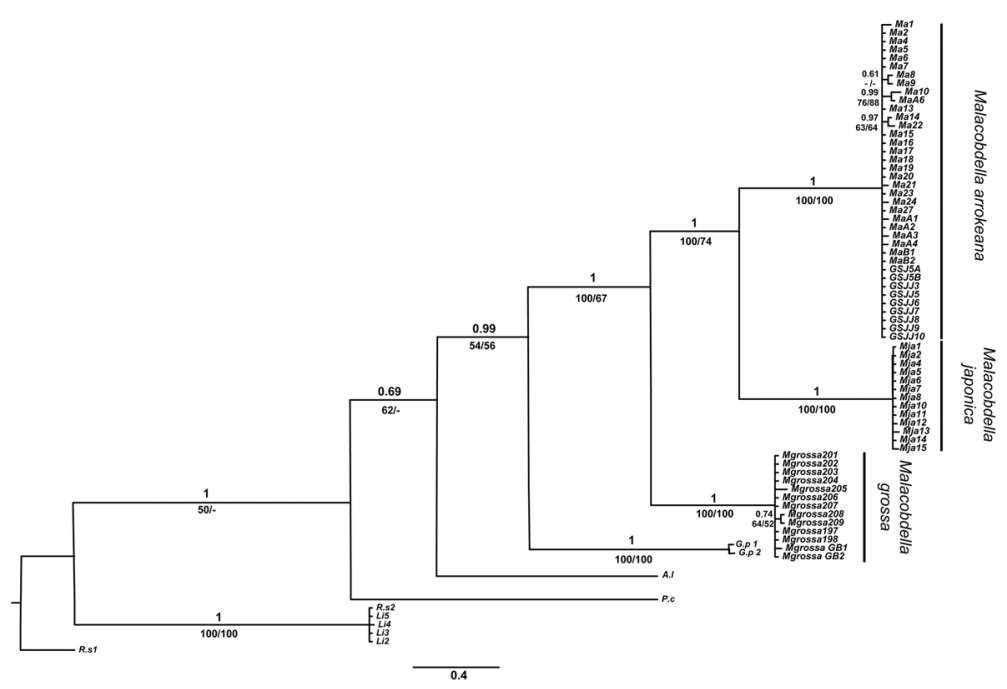

Figure 2 Haplotype phylogeny estimated by Bayesian analysis of the Malacobdella species studied. The numbers above the branches represent the posterior probabilities; the numbers below the branches represent the bootstrap percentages of the MP and ML analysis, respectively. When a certain node was not recovered by one of the methods, a hyphen was added. Ma, GSJ, M. arrokeana; Mja, M. japonica; Mgrossa, M. grossa; Li and R.s, Ramphogordius sanguineus, from Argentina and GenBank respectively; A.l, Amphiporus lactifloreus; P.c, Paradrepanophorus crassus; G.p, Geonemertes pelaensis.

DNA barcoding studies with nemerteans of the genera Tetrastemma and Cerebratulus revealed a lack of concordance between morphological and molecular characters (see Strand and Sundberg 2005; Sundberg et al. 2010). These authors argued that this difference could be the result of intraspecific variation or changes in the external morphology during development (Cantell 1975). They also concluded that the morphological characters used to describe Tetrastemma and Cerebratulus species are inadequate to identify evolutionary lineages. Our results showed that the divergence found between the sequences of the Malacobdella species (10\% to $11 \%$ between the three species) are consistent with their status as distinct species. The values here found for intra- and interspecific divergences are in agreement with values found for other nemertean groups (e.g. Sundberg et al. 2010; Chen et al. 2010; Andrade et al. 2012; Kvist et al. 2013). The only exception was the divergence obtained between samples of $R$. sanguineus, 100-fold higher than other intraspecific values, suggesting that the COI sequence from GenBank (HQ848580) is not actually from $R$. sanguineus.

The phylogenetic analysis presented here showed that $M$. arrokeana and $M$. japonica are more closely related to each other than to $M$. grossa. Further studies using more molecular markers could clarify the phylogeny of the Malacobdella genus, taking into account the high host specificity of the majority of the species versus the cosmopolitan distribution and low host specificity of $M$. grossa. In this sense, the sequence of this last species from many hosts throughout its entire distribution would clarify whether $M$. grossa is indeed a single cosmopolitan species or a complex of species.

Based on the available literature by Takakura (1897), Yamaoka (1940), Riepen (1933), Gibson (1967, 1968, 1994), Gibson and Jennings (1969), Kozloff (1991), Ivanov et al. (2002) and the present work, the positions of the proboscis muscle and the nerve commissure appear to be good diagnostic characters for identifying species within the genus Malacobdella (since they are unique characteristic autapomorphies).

Several authors have concluded that nemertean species identification based only on morphological characters could be unreliable (see Strand and Sundberg 2005; Sundberg et al. 2009; Thornhill et al. 2008; Chen et al. 2010; Fernández-Álvarez and Machordom 2013; Kvist et al. 2013). More comprehensive future studies using the results presented here may strengthen species identification of other Malacobdella species by DNA barcoding.

\section{Conclusions}

Analysis of the COI (DNA barcoding) sequences presented in this work is clearly a powerful tool for species identification, at least of the three Malacobdella species studied. These molecular data are congruent with identifications based on internal morphological characters used in the original descriptions and re-descriptions of these three species and could be used to delineate between species in this genus with a similar external morphology. 


\section{Competing interests}

The authors declare that they have no competing interests.

\section{Authors' contributions}

The work presented here was carried out in collaboration among all authors. JEFA, GB and AM defined the research theme and wrote the manuscript. JEFA, HK, MS and PS collected the samples in Argentina, Japan and Sweden, respectively, and took the photos. PS and MS provided COI sequences from M. grossa. JEFA and AM carried out the laboratory work (DNA extraction, PCR amplification, edition and sequences analysis), analysed the data and interpreted the results. JEFA prepared the tables and figures. PS, MS and HK improved the manuscript and made the English revision. All authors read and approved the final manuscript

\section{Acknowledgements}

The authors thank CONICET, Secretaría de Ciencia Tecnología e Innovación Productiva de la Provincia de Chubut, Agencia Española de Cooperación Internacional y Desarrollo (AECID: A/023484/09 and A/032441/10) and the iBOL-CONICET project, for financial support. We are grateful also to Melinda Modrell for her conscientious revision of the English.

\section{Author details}

${ }^{1}$ LARBIM, IBIOMAR- Centro Nacional Patagónico (CENPAT), CONICET, Bvd. Brown 2915, U9120ACV Puerto Madryn, Chubut, Argentina. ${ }^{2}$ Facultad de Ciencias Naturales, Universidad Nacional de la Patagonia San Juan Bosco (UNPSJB), Bvd. Brown S/N, U9120ACV Puerto Madryn, Chubut, Argentina. ${ }^{3}$ Faculty of Science, Hokkaido University, Kita 10, Nishi 8, Kita-ku, Sapporo 060-0810, Japan. ${ }^{4}$ The Swedish Species Information Centre, SLU, Bäcklösavägen 10, Box 7007, SE-750 07 Uppsala, Sweden. ${ }^{5}$ Department of Biological and Environmental Sciences, University of Gothenburg, Medicinaregatan 18, PO Box 463, SE-40530 Gothenburg, Sweden. ${ }^{6}$ Museo Nacional de Ciencias Naturales (MNCN), CSIC, José Gutiérrez Abascal, 2, 28006 Madrid, Spain.

Received: 16 March 2014 Accepted: 16 December 2014

Published online: 10 January 2015

\section{References}

Alfaya JEF, Bigatti G, Machordom A (2013) Mitochondrial and nuclear markers reveal a lack of genetic structure in the entocommensal nemertean Malacobdella arrokeana in the Patagonian gulfs. Helgoland Mar Res 67(2):407-412

Andrade SCS, Strand M, Schwartz M, Chen H, Kajihara H, von Döhren J, Sun S, Junoy J, Thiel M, Norenburg JL, Turbeville JM, Giribet G, Sundberg P (2012) Disentangling ribbon worm relationships: multi-locus analysis supports traditional classification of the phylum Nemertea. Cladistics 28:141-159

Bucklin A, Steinke D, Blanco-Bercial L (2011) DNA barcoding of marine metazoa. Annu Rev Mar Sci 3:471-508

Cantell CE (1975) Anatomy, taxonomy, and biology of some Scandinavian heteronemertines of the genera Lineus, Micrura, and Cerebratulus. Sarsia 58:89-122

Chen H, Strand M, Norenburg JL, Sun S, Kajihara H, Chernyshev AV, Maslakova SA, Sundberg P (2010) Statistical parsimony networks and species assemblages in Cephalotrichid nemerteans (Nemertea). PLoS ONE 5(9):e12885. doi:10.1371/journal.pone.0012885

Coe WR (1945) Malacobdella minuta, a new commensal nemertean. J Wash Acad Sci 35:65-67

de Blainville HM (1827) Sangsue. In: Levrault EG (ed) Dictionnaire des Sciences Naturelles, 47. Normant, Paris, pp 270-271

Felsenstein J (1985) Confidence limits on phylogenies: an approach using the bootstrap. Evolution 39:783-791

Fernández-Álvarez FÁ, Machordom A (2013) DNA barcoding reveals a cryptic nemertean invasion in Atlantic and Mediterranean waters. Helgoland Mar Res 67(3):599-605

Folmer O, Black M, Hoeh W, Lutz R, Vrijenhoek R (1994) DNA primers for amplification of mitochondrial cytochrome c oxidase subunit I from diverse metazoan invertebrates. Mol Mar Biol Biotech 3:294-299

Gibson R (1967) Occurrence of the entocommensal rhynchocoelan, Malacobdella grossa, in the oval piddock, Zirfaea crispata, on the Yorkshire coast. J Mar Biol Assoc UK 49:301-317
Gibson R (1968) Studies on the biology of the entocommensal rhynchocoelan Malacobdella grossa. J Mar Biol Assoc UK 48:637-656

Gibson R (1994) Nemerteans. Synopses of the British fauna (new series, no. 24), 2nd edn. The Dorset Press, Dorchester, UK

Gibson R (1995) Nemertean genera and species of the world: an annotated checklist of original names and description citations, synonyms, current taxonomic status, habitats and recorded zoogeographic distribution. J Nat Hist 29:1-562

Gibson R, Jennings JB (1969) Observations on the diet, feeding mechanisms, digestion and food reserves of the entocommensal rhynchocoelan Malacobdella grossa. J Mar Biol Assoc UK 49:17-32

Huelsenbeck JP (2000) MrBayes: Bayesian inference of phylogeny. University of Rochester, Rochester, NY, Department of Biology

Huelsenbeck JP, Ronquist F (2001) MrBayes: Bayesian inference of phylogeny. Bioinformatics 17:754-755

Ivanov VA, Bigatti G, Penchaszadeh PE, Norenburg JL (2002) Malacobdella arrokeana (Nemertea: Bdellonemertea), a new species of nemertean from the southwestern Atlantic Ocean entocommensal in Panopea abbreviata (Bivalvia, Heterodonta, Hiatellidae) in Argentina. P Biol Soc Wash 115:359-367

Jensen K, Sadeghian PS (2005) Nemertea. In: Rohde K (ed) Marine parasitology. CSIRO press, Australia, pp 205-210

Junoy J, Andrade SCS, Giribet G (2010) Phylogenetic placement of a new hoplonemertean species commensal on ascidians. Invertebr Syst 24:616-629

Kajihara H, Olympia M, Kobayashi N, Katoh T, Chen HX, Strand M, Sundberg P (2011) Systematics and phylogeny of the hoplonemertean genus Diplomma (Nemertea) based on molecular and morphological evidence. Zool J Linn Soc 161:695-722

Kozloff EN (1991) Malacobdella siliquae sp. nov. and Malacobdella macomae sp. nov., commensal nemerteans from bivalve mollusks on the Pacific coast of North America. Can J Zool 66:1612-1618

Kvist S, Laumer C, Junoy J, Giribet G (2013) New insights into the phylogeny, systematics and DNA barcoding of Nemertea. Invertebr Syst 28:287-308

Linnaeus C (1758) Systema naturae per regna tria naturae: secundum classes, ordines, genera, species, cum characteribus, differentiis, synonymis, locis, vol I, 10th edn. Laurentius Salvius, Stockholm, pp 824

Linnaeus C (1767) Systema naturae per regna tria naturae, secundum classes, ordines, genera, species, cum characteribus \& differentiis. Vol. II. Salvius, Holmiae, p 735

Machordom A, Araujo R, Erpenbeck D, Ramos MA (2003) Phylogeography and conservation genetics of endangered European Margaritiferidae (Bivalvia: Unionoidea). Biol J Linn Soc 78:235-252

Maslakova SA, von Döhren J (2009) Larval development with transitory epidermis in Paranemertes peregrina and other hoplonemerteans. Biol Bull 216:273-292

Mateos E, Giribet $G$ (2008) Exploring the molecular diversity of terrestrial nemerteans (Hoplonemertea, Monostilifera, Acteonemertidae) in a continental landmass. Zool Scr 37:235-243

Müller OF (1776) Zoologiae Danicae prodromus, seu Animalium Daniae et Norvegiae indigenarum characters, nomina, et synonyma imprimis popularium. Typis Hallageriis, Havniae, Copenhagen

Posada D (2003) Using Modeltest and PAUP* to select a model of nucleotide substitution. In: Baxevanis AD, Davison DB, Page RDM, Petsko GA, Stein LD, Stormo GD (eds) Current protocols in bioinformatics. John Wiley \& Sons, New York, pp 6.5.1-6.5.14

Posada D (2008) jModelTest: phylogenetic model averaging. Mol Biol Evol 25:1253-1256

Puerta P, Andrade SCS, Junoy J (2010) Redescription of Lineus acutifrons Southern, 1913 (Nemertea) and comments on its phylogenetic position. J Nat Hist 44:37-40

Riepen O (1933) Anatomie und histologic von Malacobdella grossa (Müll.). Z Wiss Zool Abt A 143:323-496

Strand M, Sundberg P (2005) Delimiting species in the hoplonemertean genus Tetrastemma (phylum Nemertea): morphology is not concordant with phylogeny as evidenced from mtDNA sequences. Biol J Linn Soc 86:201-212

Strand M, Hererra-Bachiller A, Nygren A, Kånneby T (2014) A new nemertean species: what are the useful characters for ribbon worm descriptions? J Mar Biol Assoc UK 94:317-330

Sundberg P, Strand M (2010) Nemertean taxonomy - time to change lane? J Zool Syst Evol Res 48:283-284

Sundberg P, Thuróczy Vodoti E, Zhou H, Strand M (2009) Polymorphism hides cryptic species in Oerstedia dorsalis (Nemertea, Hoplonemertea). Biol J Linn Soc 98:556-567 
Sundberg P, Vodoti E, Strand M (2010) DNA barcoding should accompany taxonomy the case of Cerebratulus spp. (Nemertea). Mol Ecol Res 10:274-281 Swofford DL (2000) PAUP*. Phylogenetic analysis using parsimony (*and other methods), Version 4. Sinauer Associates, Sunderland, Massachusetts, USA

Taboada S, Junoy J, Andrade SCS, Giribet G, Cristobo J, Avila C (2013) On the identity of two Antarctic brooding nemerteans: redescription of Antarctonemertes valida (Burger, 1893) and description of a new species in the genus Antarctonemertes Friedrich, 1955 (Nemertea, Hoplonemertea). Polar Biol 36:1415-1430

Takakura U (1897) On a new species of Malacobdella (M. japonica). Annot Zool Japon 1:105-112

Teso SV, Bigatti G, Bazterrica MC, Ciocco NF, Penchaszadeh PE (2006) The reproductive cycle of the entocommensal nemertean Malacobdella arrokeana and its symbiosis with the geoduck Panopea abbreviata. Invertebr Biol 125(4):314-324

Thollesson M, Norenburg JL (2003) Ribbon worm relationships: a phylogeny of the phylum Nemertea. P Roy Soc Lond B Biol 270:407-415

Thornhill DJ, Mahon AR, Norenburg JL, Halanych KM (2008) Open-ocean barriers to dispersal: a test case with the Antarctic Polar Front and the ribbon worm Parborlasia corrugatus (Nemertea: Lineidae). Mol Ecol 17:5104-5117

Wiens JJ (2007) Species delimitation: new approaches for discovering diversity. Syst Biol 56:875-878

Yamaoka T (1940) The fauna of Akkeshi Bay. IX. Nemertini. J Fac Sci, U Hokkaido 6(7):205-261

\section{Submit your manuscript to a SpringerOpen ${ }^{\circ}$ journal and benefit from:}

- Convenient online submission

- Rigorous peer review

- Immediate publication on acceptance

- Open access: articles freely available online

- High visibility within the field

- Retaining the copyright to your article

Submit your next manuscript at $>$ springeropen.com 